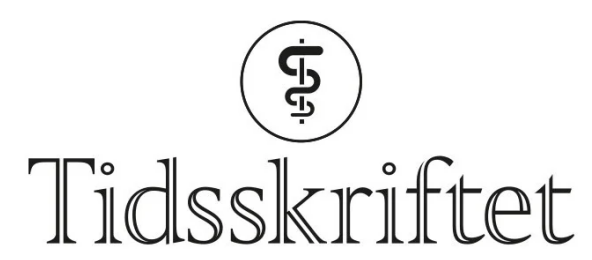

DEN NORSKE LEGEFORENING

\title{
En fengende innføring i statistikk
}

\author{
ANMELDELSER
}

MARIANNE RIKSHEIM STAVSETH

Postdok, Avdeling rus- og avhengighetsbehandling

Oslo universitetssykehus

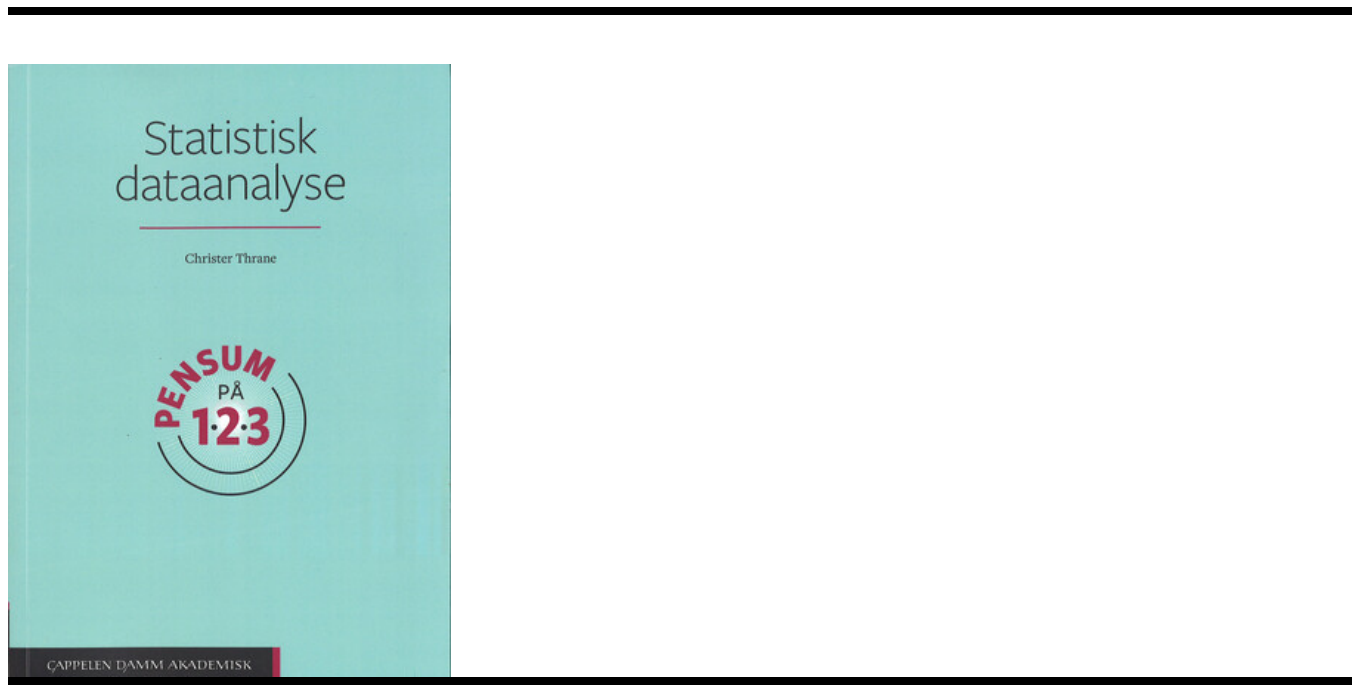

Christer Thrane

Statistisk dataanalyse på 1-2-3

140 s, tab, ill. Oslo: Cappelen Damm Akademisk, 2020. Pris NOK 229

ISBN 978-82-02-63851-1

Statistisk dataanalyse på 1-2-3 er en enkel innføringsbok i det store temaet statistikk. Boken sikter seg mot personer som ønsker kjennskap til hvordan statistisk analyse utføres, og hvordan den bør tolkes, formidles og vurderes. Den inneholder få formler og ligninger, og krever ingen forkunnskaper annet enn et ønske om å lære.

Boken inneholder seks kapitler. Den starter med en forklaring av hva som menes med statistisk dataanalyse, og av hvordan data kan oppsummeres, før forfatteren beveger seg videre til sentrale temaer som samvariasjon, årsak og virkning, statistisk signifikans og formidling av statistiske analyser. Forfatteren benytter fotnoter til presiseringer, utdypninger og referanser. Hvert kapittel avsluttes med en kortfattet, beskrivende oppsummering. 
Jevnt over er teksten lettlest med enkle og oppdaterte eksempler som tidvis gjør at en (statistiker iallfall) trekker på smilebåndet. Det skinner igjennom at boken er skrevet av en person som er svært opptatt av å formidle de nyttige, og fascinerende, sidene ved statistisk dataanalyse. Leseren motiveres til å lese videre, og spesielt delkapittelet «Vi er alle gode hverdagsstatistikere, eller?» fungerer godt til dette formålet.

En stor utfordring ved bøker av denne typen er balansegangen mellom presise detaljer og leservennlig enkelhet. Stort sett fungerer dette svært godt i boken, og i de tilfellene hvor det gjerne kunne vært gitt mer detaljer, poengterer forfatteren dette og gir referanser til mer utfyllende litteratur. Til tross for at boken er lettlest og holder et nokså overfladisk nivå teknisk sett, har den mange gode poenger som selv personer med mye erfaring i statistisk dataanalyse kan ta med seg.

Personlig synes jeg forfatteren spesielt godt tar opp problemstillinger knyttet til kausalitet versus samvariasjon. Det gis en innføring i både forskjellen mellom begrepene og hvordan fors $ø$ ksdesign påvirker analysen, samt hvordan de to begrepene fremstilles (og misforstås!) i media.

Denne boken gir en god innføring i hva statistisk dataanalyse er, hvorfor det er viktig, og hvorfor alle og enhver bør ha grunnleggende kjennskap til feltet. I det store og det hele er dette en bok som treffer målgruppen svært godt og gjør leseren bedre rustet til kritisk å tolke den store mengden statistikk vi møter i hverdagen.

Publisert: 22. februar 2021. Tidsskr Nor Legeforen. DOI: 10.4045/tidsskr.20.0854

(C) Tidsskrift for Den norske legeforening 2023. Lastet ned fra tidsskriftet.no 26. april 2023. 